\title{
Timing and spatial distribution of deformation in the Newfoundland Appalachians: a "multi-stage collision" history
}

\author{
BEN A. VAN DER PLUIJM \\ Department of Geological Sciences, University of Michigan, 1006 C.C. Little Building, Ann Arbor, MI 48109 (U.S.A.)
}

(Received August 23, 1985; revised version accepted June 1, 1986)

\begin{abstract}
Van der Pluijm, B.A., 1987. Timing and spatial distribution of deformation in the Newfoundland Appalachians: a “multi-stage collision" history. In: H.J. Zwart, M. Martens, I. van der Molen, C.W. Passchier, C. Spiers and R.L.M. Vissers (Editors), Tectonic and Structural Processes on a Macro-, Meso- and Micro-Scale. Tectonophysics, 135: 15-24.

The Newfoundland Appalachians have been interpreted as an area where Lower Paleozoic plate convergence culminated in collision between an Ordovician volcanic chain and the North American craton in Middle Ordovician times. Closure of the intervening proto-Atlantic (Iapetus) ocean was considered incomplete. Subsequent deformation gave rise to regional folding and faulting.

Recent studies in the Newfoundland Dunnage zone have revealed that the deformation history is far more complex than previously recognized. Large-scale thrusting, folding and faulting occurred in Silurian-Devonian times. Furthermore, it has been suggested that the Dunnage zone is an allochthonous terrane underlain by dominantly continental crust rather than representing remnants of a "rooted" ocean basin.

In view of these results a revision of tectonic scenarios and zonal subdivision is warranted and a "multi-stage collision" history will be discussed, with emphasis on the spatial distribution and significance of Silurian-Devonian deformation in central Newfoundland.

Subduction in Lower Paleozoic times gave rise to the formation of a volcanic terrane; concurrently, to the southeast a marginal sea was formed (Mariana-type subduction). In Middle Ordovician times the volcanic terrane collided with the North American craton ("first-stage collision") and back-arc spreading terminated. Continued crustal shortening resulted in the formation of a Silurian accretionary terrane (telescoped marginal sea), and its subsequent deformation ("second-stage collision"). Devonian (-Carboniferous?) strike-slip faulting represents the third stage in the collision history.

The model is applicable to large tracts of the Caledonian-Appalachian chain. Its main characteristics are: (a) the revised zonal subdivision of the area is based on characteristics of Silurian and older rocks, rather than Middle Ordovician and older rocks only; (b) the central part of the orogen represents a telescoped marginal sea that formed to the southeast of the Ordovician volcanic chain, rather than a remnant of the incompletely closed Iapetus ocean; (c) the earliest deformation is progressively younger toward the southeast; (d) the Appalachian collision history is a result of the activity of a single deformation regime over a long period of at least $75 \mathrm{Ma}$.
\end{abstract}

\section{Introduction}

The Canadian Appalachians (Newfoundland, Prince Edward Island, New Brunswick, Nova Scotia and part of Quebec) have provided the testing ground for geotectonic modeling in ancient orogens over the past twenty years. Since the interpretation presented in this paper in more than one way draws on these earlier models and concepts, a brief historic overview is given below.

Williams (1964) recognized three zones in Newfoundland, which resulted in the view of a two- 
sided, symmetrical orogen: northwestern margin, ocean, southeastern margin. These zones were labeled the Western Platform (Kay and Colbert, 1965), the Central Palaeozoic Mobile Belt (Williams, 1964) and the Avalon Platform (Kay and Colbert, 1965), respectively.

Wilson (1966) in his hypothesis of an opening and closing proto-Atlantic ocean (the "Wilsoncycle") introduced plate tectonics to the northern Appalachians.

Dewey (1969) and Bird and Dewey (1970) succesfully interpreted the rock distribution in the Newfoundland Appalachians in view of the seafloor spreading concept. This prompted a host of other papers discussing various aspects of their model (e.g., Church and Stevens, 1971; Dewey and Bird, 1971; Kay, 1972, 1976; Williams et al., 1972, 1974; Strong et al., 1974; Kennedy, 1975; Haworth et al., 1978; Colman-Sadd, 1982; and others). Among the major points of controversy was the polarity of subduction. Eastward and westward subduction, as well as combinations of both have been proposed.

Williams et al. (1972, 1974) distinguished tectonostratigraphic zones in the northern Appalachians, which were defined as fault-bounded terranes with a distinct tectonic and stratigraphic history. Their nine-part zonal subdivision was later reduced to five major zones. Williams (1978a; 1978b) recognized from the northwest to the southeast the Humber, Dunnage, Gander, Avalon and Meguma zones. The zonal subdivision is based on stratigraphic and structural contrasts between Middle Ordovician and older rocks.

The Humber zone records the development and destruction of an Atlantic-type margin (North American craton); the Dunnage zone represents the Ordovician volcanic chain and vestiges of the proto-Atlantic (lapetus) ocean; the Gander zone was, at least locally, an Andean-type margin; the Avalon zone was a stable platform (Avalonia) during the Appalachian orogeny, locally with Silurian/Devonian volcanics; the Meguma zone originally formed part of the African craton (Williams, 1979).

Three orogenic stages were responsible for the formation of the Appalachians (for reviews see: Schenk, 1978; Williams, 1979; Rodgers, 1982; De- wey et al., 1983; McKerrow, 1983; Williams and Hatcher, 1983). The main event, the Taconic orogeny, represents the collision between the Ordovician volcanic terrane and the North American craton in Middle Ordovician times. In Newfoundland the intervening ocean was incompletely closed. The Iapetus suture is marked by the Reach-Cape Ray Fault (McKerrow and Cocks, 1977; cf. Karlstrom et al., 1982). The Acadian orogeny in Devonian times records collision between the North American plate (with accreted volcanic chain) and Avalonia, and is considered to have been of lower intensity than the Taconic event. The third orogenic stage in Upper Paleozoic times (Alleghanian) is associated with further plate interactions (e.g., emplacement of the Meguma zone).

In the 1980's the "suspect terrane" concept (Coney et al., 1980) has been applied to the Appalachians (Williams and Hatcher, 1982, 1983; Williams, 1984). The orogen formed as a result of a series of accretionary events, rather than one single subduction event, which include large-scale strike-slip faulting. The main accretionary event in the northern Appalachians, however, was still considered to have occurred in Middle Ordovician times. In the northern Appalachians the suspect terrane boundaries coincide with the earlier defined tectonostratigraphic zones and, similarly, are

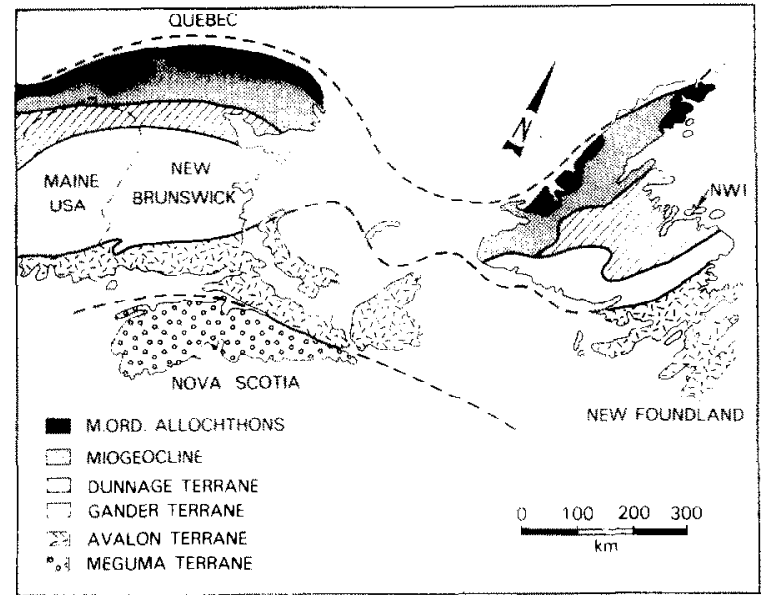

Fig. 1. Terranes in the northern Appalachians (from Williams and Hatcher, 1983). The miogeocline is the margin of the North American craton. The location of New World Island is indicated $(N W I)$. 
also based on contrast between Middle Ordovician and older rocks. In Fig. 1 the interpreted suspect terranes of the northern Appalachians are shown (from Williams and Hatcher, 1983).

Rather than a comprehensive review of the geological history of the Newfoundland Appalachians, this paper is intended as a discussion of events in view of the timing, sequence and style of deformation in this part of the Appalachian-Caledonian chain. The focus is on the deformation history of the central part of the region, the Dunnage and Gander zones, and its implications for the tectonic interpretation. For a discussion of the sedimentology, stratigraphy, paleontology and geochemistry of the area the reader is referred to the vast body of literature on these topics (for reviews and comprehensive literature, see Strong, 1977; Schenk, 1978; Williams, 1979, 1984; McKerrow, 1983).

\section{The Dunnage zone}

\section{Stratigraphy}

The generalized stratigraphic sequence in the Dunnage zone of Newfoundland, mainly based on reported fossil ages (Dean, 1978; Kean et al., 1981; Neuman, 1984; Van der Pluijm, 1984a, 1986; Arnott et al., 1985), can be summarized as follows. Ophiolitic rocks (Tremadoc to Arenig-Dunning and Krogh, 1985) underlie a Lower to Middle Ordovician volcanic sequence, with limestone, sandstone and shale interbeds. This sequence is conformably overlain by limestones (Llandeilo), followed by Caradocian graptolitic shales (with local disconformity). Overlying this black shale unit is a coarsening-upward greywacke (turbidites) and conglomerate sequence which yielded Upper Ordovician (Ashgill) to Lower Silurian (Llandovery) fossils. The latter is overlain by subaerial volcanics and sandstones (Upper Silurian). The youngest rocks in the area are Carboniferous in age.

This generalized sequence is remarkably similar to stratigraphic sequences recognized in other parts of the Caledonian-Appalachian chain. For example, in the central and southern Appalachians (Shanmugam and Lash, 1982; Hiscott, 1984) and in the British Isles (Leggett et al., 1979).

\section{Deformation history}

Recent studies on New World Island and surrounding areas in the northeastern Dunnage zone (Fig. 1; Karlstrom et al., 1982; Van der Pluijm, 1984a, 1986) revealed the following deformation sequence. The first (progressive) deformation generation $\left(D_{1}\right)$ is associated with thrusting and is Lower Silurian in age. $D_{1}$ is overprinted by a regional cleavage and associated folding $\left(F_{2}\right)$, probably of Lower Devonian age. Large-scale, strike-slip faulting (locally associated with $F_{3}$ folding) occurred in post-Lower Devonian times. Kinking $\left(F_{4}\right)$ is related to dip-slip faulting, and comprises the youngest deformation recognized in the area. Similar deformation sequences have been reported from other parts of the Newfoundland Dunnage zone (e.g., Nelson, 1981).

For the present discussion $D_{1}$ deformation is most relevant, as it (a) shows that the Dunnage zone is an allochthonous terrane rather than an authochtonous ocean remnant and (b) demonstrates that the earliest deformation in the Dunnage zone is post-Middle Ordovician in age and, therefore, distinct from the Middle Ordovician main event in areas to the west (Humber zone).

Although thrusting was earlier reported from the Newfoundland Dunnage zone (Kay and Williams, 1963; Jacobi and Schweickert, 1976; Dean and Strong, 1977; Kidd, 1977; Blackwood, 1979; Pajari et al., 1979), it has recently become more widely recognized and better understood (Colman-Sadd, 1980; Nelson, 1981; Thurlow, 1981; Blackwood, 1982; Karlstrom et al., 1982, 1983; Colman-Sadd and Swinden, 1984; Van der Pluijm, 1984a, 1986; Kusky and Kidd, 1985). For example, Colman-Sadd and Swinden (1984) document a tectonic window ("Tim Horton structure") in the Trough Hill area (Fig. 2) exposing Gander zone metamorphosed sandstones and shales overlain by ophiolitic and volcaniclastic rocks of the Dunnage zone. They interpreted this structure as a result of southeast-directed thrusting of the ophiolite sequence in Upper Silurian times. Using the above generalized stratigraphic sequence, other fault-controlled repetitions have been recognized in the northern Dunnage zone (Van der Pluijm, 1984a). In conclusion, therefore, it is apparent that 


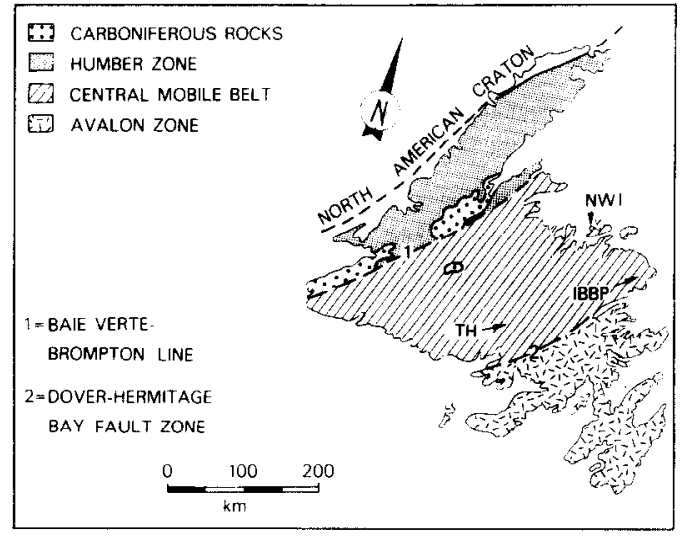

Fig. 2. Zonal subdivision of the Newfoundland Appalachians. Numbers refer to faulted boundaries. Locations of areas used in the text are: $I B B P$--Indian Bay Big Pond; NWI-New World Island; $T H-$ Trough Hill.

thrusting was a major event in the central part of the Newfoundland Appalachians.

The direction of thrusting remains insufficiently known (Van der Pluijm and Williams, 1985). The majority of workers have concluded (south)eastward-directed thrusting (e.g., Nelson, 1981; Thurlow, 1981; Blackwood, 1982; ColmanSadd and Swinden, 1984; Kusky and Kidd, 1985). This is in disagreement with the reported northeasterly thrusting of a subaerial rock sequence on the Port Albert Peninsula, to the south of New World Island (Karlstrom et al., 1982). However, the relationship of this thrust sequence to thrusts on New World Island (Van der Pluijm, 1986), and ongoing detailed structural studies in surrounding areas indicate that two thrusting events may have occurred.

\section{Nature of "basement" and volcanic rocks}

The nature of the rocks underlying the Dunnage zone ("basement") and the tectonic setting of mafic volcanics are topics of considerable discussion, which bear directly on attempts to present a geotectonic model for the region.

Karlstrom (1983) quantitatively reevaluated existing geophysical data and concluded that the presence of continental rather than oceanic crust is in better agreement with the observed anomalies (see also Miller, 1984 with references). This inter- pretation appears to be confirmed by the nature of the Devonian granites in the area (Bell et al., 1977). As a consequence, the Dunnage zone is now considered to be an allochthonous oceanic terrane (Karlstrom et al., 1982; Karlstrom, 1983; Colman-Sadd and Swinden, 1984; Van der Pluijm, 1986; Keen et al., 1986), largely underlain by continental crust.

The majority of Lower to Middle Ordovician volcanic rocks have been interpreted as part of an island arc succession (Kean and Strong, 1975; Strong, 1977; Dean, 1978; Swinden and Thorpe, 1984). Reusch (1983), Jacobi and Wasowski (1985) and Wasowski and Jacobi (1985), however, concluded that, on the basis of clinopyroxene and whole-rock geochemistry, basalts of the New World Island area (Fig. 2) are not of island-arc affinity. Jacobi and Wasowski (1985) favour an ocean island setting for these tholeiitic and alkalic transitional basalts. They further state, however, that these "within-plate" basalts may also represent mid-ocean ridge tholeiites.

Correlatives of these basalts are present throughout the northern part of the Dunnage zone (Dean, 1978; Kean et al., 1981; Arnott et al., 1985; Wasowski and Jacobi, 1985), which indicates that a significant portion of the Ordovician volcanic rocks in the Dunnage zone do not represent remnants of an Ordovician island-arc terrane.

\section{Revised zonal subdivision: the Central Mobile Belt}

The original five-part zonal subdivision in the northern Appalachians was based on contrasts in stratigraphy and deformation in Middle Ordovician and older rocks (e.g. Williams, 1979). As was demonstrated in an earlier section, the main orogenic stage in the central part of the Newfoundland Appalachians took place in post-Middle Ordovician times. Therefore, the post-Middle Ordovician history of the area should also be considered in making a regional subdivision.

Pre-Middle Ordovician rocks of the Gander zone (Fig. 1), mainly comprising sandstones and quartzites, have been interpreted as a clastic wedge (shelf facies) at the eastern margin of the Iapetus ocean (e.g. Blackwood, 1982). They are distinctly different from rocks with similar ages in the Dun- 
nage zone (mainly volcanics). The boundary between these two zones, locally, is a reverse fault (Pajari and Currie, 1978; Blackwood, 1979, 1982; Wilton, 1983). In the southeast, however, the contact is gradational (Currie et al., 1979; Pajari et al., 1979; Colman-Sadd, 1980; Blackwood, 1982; Colman-Sadd and Swinden, 1984). Pickerill et al. (1978) and Blackwood (1982), therefore, suggested that Gander zone rocks are lateral correlatives of Dunnage zone rocks. Furthermore, fossils with Dunnage zone affinity and Lower to Middle Ordovician ages have been collected from rocks overlying Gander zone quartzose rocks near Indian Bay Big Pond (Fig. 2). The nature of the contact between these two rock associations is, however, yet imprecisely known (Wonderley and Neuman, 1984; Neuman, pers. commun., 1985).

Combined, these relationships indicate that the Dunnage and Gander zones were spatially linked from at least Middle Ordovician times onward.

Thrusting, folding and strike-slip faulting with ages comparable to similar events in the Dunnage zone have been reported from the Gander zone (Kennedy and McGonigal, 1972; Blackwood, 1978; 1982; Hanmer, 1981; Wilton, 1983; Chorlton and Dallmeyer, 1986). This would suggest that the two zones were closely related in Silurian and younger times. In the absence, however, of more detailed structural work in both zones, a correlation on the basis of deformation characteristics is not undertaken at this stage.

Finally, it is noteworthy that in southern New Brunswick (Fig. 1), a similar relationship between Dunnage and Gander zone rocks exists (Van der Pluijm, 1984a).

Thus, in contrast to the view of the Dunnage and Gander zones as two separate terranes, it appears more useful to combine them into one single terrane: the Central Mobile Belt (Fig. 2; see also Colman-Sadd and Swinden, 1984); as was originally done in Williams's (1964) three-fold subdivision ("Central Palaeozoic Mobile Belt"). This appears confirmed by recent results obtained from deep seismic reflection profiling across the northern part of Newfoundland (Keen et al., 1986). The difference between the significance of the area in the interpretation presented in this paper and that of other workers (e.g. Haworth et al., 1978;
Williams, 1979), is that (a) the earliest deformation occurred in post-Middle Ordovician times, in contrast to that in areas to the west (Humber zone) where the main event was in Middle Ordovician times, and (b) the area represents a telescoped marginal sca, rather than a remnant of the incompletely closed Iapetus ocean basin (see below).

\section{A geotectonic model for the Newfoundland Appa- lachians}

The results of ongoing detailed structural mapping in the northeastern Dunnage zone and related areas in the Newfoundland Appalachians places important constraints on geotectonic modeling for the northern Appalachians (Van der Pluijm, 1984b). The major deformational events in the Newfoundland Appalachians, from Lower Ordovician to Silurian times, with the emphasis on the central part of the mountain belt, are schematically shown in Fig. 3.

The formation of the Iapetus ocean (Fig. 3a) was followed by subduction (and, locally, obduction; Dewey and Shackleton, 1984) of the ocean floor in Lower to Middle Ordovician times and associated formation of a volcanic chain (e.g. Williams, 1979) at, or close to, the southeastern continental margin (Avalonia, Fig. 3b; see also Swinden and Thorpe, 1984). Remnants of this volcanic terrane are, for example, the Twillingate terrane (Williams and Payne, 1975) and the Lushs Bight terrane (Dean, 1978; S. Armstrong, pers. commun., 1984; Arnott et al., 1985) to the north of New World Island.

Associated with subduction, spreading in the back-arc region was initiated (deposition of MORB-type volcanics and Dunnage Mélange), which continued into Middle Ordovician times (Fig. 3c). Following the classification of Uyeda and Kanamori (1979), the tectonic model presented here is Mariana-type subduction.

Cessation of back-arc spreading coincided with collision of the volcanic chain with the North American craton in Middle Ordovician times ("first-stage collision", Fig. 3d), as is demonstrated by Llanvirnian ages for both the emplacement of the west coast allochthons (Williams, 


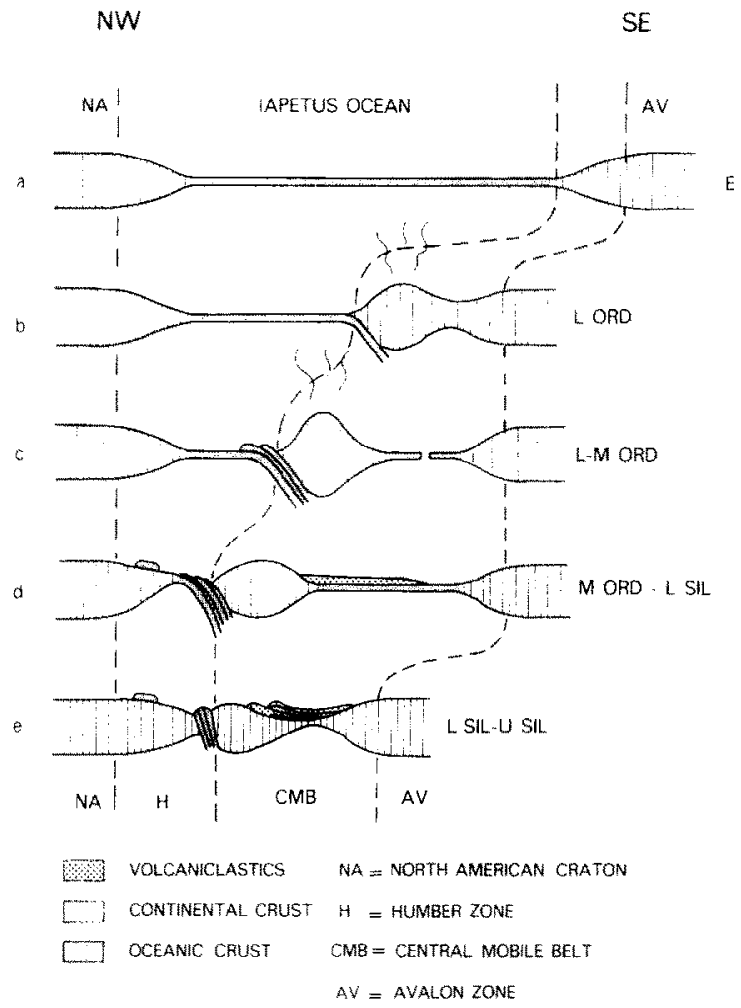

Fig. 3. Lower Ordovician to Silurian tectonic history of the Newfoundland Appalachians. In (a) to (c) subduction of the Iapetus Ocean results in the formation of a volcanic chain (b), and a marginal sea, southeast of the chain (c). Collision between the volcanic chain and the North American craton is responsible for the "first-stage collision" (d). Closure of the marginal sea is associated with the "second-stage collision" (e). See text for further discussion.

1975), and the top of the Ordovician volcanic sequence in the Central Mobile Belt (e.g. Dean, 1978). Subsequent progressive erosion of the volcanic chain to the north is recorded by Upper Ordovician and Lower Silurian clastic deposition in the area (McKerrow and Cocks, 1978; Watson, 1981).

Deformation in the Central Mobile Belt was active from Lower Silurian (and possibly Upper Ordovician) times onward. A series of thrusts were stacked into a thrust pile during closure of the marginal sea ("second-stage collision", Fig. 3e), which was accompanied by a generally shallowing depositional environment. Because of the two reported thrusting directions (NW and SE) and our yet incomplete knowledge of the geometry of the area, both thrusting directions were tentatively used in the construction of Fig. 3e. It is noteworthy that thrusting in the northern part of the Central Mobile Bell is of Lower Silurian age (Nelson, 1981; Karlstrom et al., 1982; Kusky and Kidd, 1985; Van der Pluijm, 1986); on the other hand, thrust emplacement in the Trough Hill area to the southeast (Fig. 2) took place in Upper Silurian times (Colman-Sadd and Swinden, 1984). This may indicate that thrusting generally becomes younger toward the southeast, which is consistent with the interpretation of the area as an accretionary terrane (Van der Pluijm, 1986).

Continued crustal shortening was responsible for superimposed $F_{2}$ deformation. Crustal thickening as a result of $D_{1}$ thrusting may have caused the change from $D_{1}$ deformation to $F_{2}$ folding. The continued regional shortening was more easily accommodated by folding of the already existing thrust pile, than by continued thrusting.

Subsequent (Devonian/Carboniferous) strikeslip faulting in the area may be associated with (a) a major crustal shear zone as a result of differences in motion between the North American and African plates (Arthaud and Matte, 1977; Gates et al., 1986), or (b) a result of continued crustal shortening. In the latter interpretation. transcurrent faulting would represent the "thirdstage collision" in the Appalachian tectonic history, which resulted from the activity of the same deformation regime that was responsible for the two other stages.

It has recently been suggested that large-scale sinistral movements in the Caledonian-Appalachian chain occurred in Silurian to Lower Devonian times (Dewey and Shackleton, 1984). However, in central Newfoundland the earliest strikeslip faulting post-dates deposition of Upper Silurian (Ludlovian) rocks, and, consequently, is at least latest Silurian and more likely Devonian in age.

The three stages in the collision history described above are not present throughout the orogen, nor everywhere of the same intensity. In the northwest the Ordovician collision event ("first-stage") is overprinted by Silurian-Devonian deformation ("second-stage"), which resulted in the presence of angular unconformities 
in the Humber zone (Rodgers, 1965; Bergstrom et al., 1974). On the other hand, pre-Upper Ordovician deformation has not occurred in the central part of the orogen, and, therefore, angular unconformities were not recognized (Karlstrom et al., 1982, 1983; Van der Pluijm, 1986). This indicates that the initiation of deformation has been diachronous and younger toward the southeast (see also Williams and Hatcher, 1983; P.F. Williams, 1984). A distinction should be made for strike-slip faulting, which can be observed throughout the area, but is restricted to relatively narrow fault zones enclosing lozenge-shaped domains (P.F. Williams, 1984).

From the displacement pattern of the various deformation events in the Newfoundland Appalachians the total deformation history can be interpreted as a result of regional NW-SE shortening in a deformation regime that was active from at least Middle Ordovician to Lower Devonian times, i.e. $75 \mathrm{Ma}$ or more.

The tectonic interpretation for the Newfoundland Appalachians presented in this paper, provides additional support for the view of a unified model for the Caledonian-Appalachian orogen, as was initiated by Dewey (1969). A somewhat modified version of this "multi-stage collision" model has successfully been applied to New Brunswick (Van der Pluijm, 1984a; Van Staal, 1985), and has previously been suggested for the central Appalachians (Osberg, 1978; Bradley, 1983).

The northeastern continuation of the Central Mobile Belt in Great Britain, the Southern Uplands of Scotland, has been interpreted as a Lower Paleozoic accretionary prism (McKerrow et al., 1977; Leggett et al., 1983) with a deformation history very similar to that recognized in Newfoundland (Stringer and Treagus, 1981; Knipe and Needham, 1985). The steep dips of bedding in the Southern Uplands are considercd a result of progressive steepening of the thrust slices as was proposed for accretionary prisms (e.g. Karig and Sharman, 1975). However, the presence of large scale $F_{1}$ folds in the northeastern Dunnage zone (Van der Pluijm, 1984a) is at variance with the geometry of the Southern Uplands and necessitates further investigation.

\section{Conclusion}

The timing of orogenic events, and the spatial distribution and style of deformation in the Newfoundland Appalachians indicate that plate convcrgence has been active from Middle Ordovician to, at least, Devonian times. However, deformation is not everywhere of the same age, nor of the same intensity.

As a consequence, revision of the zonal subdivision in the area is proposed, which includes deformational and stratigraphic characteristics of Middle Ordovician and older rocks, as well as Upper Ordovician and Silurian rocks. The Dunnage and Gander zones (or terranes) were, therefore, combined into the Central Mobile Belt.

A "multi-stage collision" model is proposed for the Newfoundland Appalachians with the following characteristics:

(a) the total deformation history consists of a series of collision stages with a discrete distribution across the orogen;

(b) these stages occurred as a result of the activity of the same overall deformation regime (NW-SE crustal shortening);

(c) the initiation of deformation was progressively later toward the southeast;

(d) the Central Mobile Belt records the formation in Ordovician times, and subsequent destruction of a marginal sea that formed southeast of the Ordovician volcanic chain;

(e) the Newfoundland Appalachians are an example of a deformed Mariana-type orogen.

\section{Acknowledgements}

This paper is based, in part, on a Ph.D. thesis completed at the University of New Brunswick, Canada. Discussions with a great number of fellow workers, notably R.J. Arnott, P.L. Dean, R.J. Jacobi, K.E. Karlstrom, W.S. McKerrow, R.K. Pickerill, D.N. Reusch, P. Stringer, C.R. van Staal, H. Williams and, especially, P.F. Williams, considerably contributed to my knowledge of Newfoundland geology.

Research was supported by NSERC grants (to P.F. Williams) and by the Universities of New Brunswick and Michigan. Illustrations were pre- 
pared by the technical staff of the IVA at Utrecht, the Netherlands.

\section{References}

Arnott, R.J., Mckerrow, W.S. and Cocks, L.R.M., 1985. The tectonics and depositional history of the Ordovician and Silurian rocks of Notre Dame Bay, Newfoundland. Can. J. Earth Sci., 22: 607-618.

Arthaud, F. and Matte, P., 1977. Late Paleozoic strike-slip faulting in southern Furope and northern Africa: result of a right-lateral shear zone between the Appalachians and the Urals. Geol. Soc. Am. Bull, 88: 1305-1320.

Bell, K., Blenkinsop, J. and Strong, D.F., 1977. The geochronology of some granite bodies from eastern Newfoundland and its bearing on Appalachian evolution. Can. I. Earth Sci., 14: 456-476

Bergstrom, S.M., Riva, J. and Kay, M., 1974. Significance of conodonts, graptolites and shelly faunas from the Ordovician of western and north-central Newfoundland. Can. J, Earth Sci., 11: 1625-1660.

Bird, J.M. and Dewey, J.F., 1970. Lithosphere plate-continental margin tectonics and the evolution of the Appalachian Orogen. Geol. Soc. Am. Bull, 81: 1031-1060.

Blackwood, R.F., 1978. Northeastern Gander Zone, Newfoundland. Newfoundland Dep. Mines Energ., Min. Dev. Div., Rep. 78-1: 72-79.

Blackwood, R.F., 1979. Geology of the Gander River area (2E/2), Newfoundland. Newfoundland Dep. Mines Energ., Min. Dev. Div, Rep. 79-1: 38-42.

Blackwood. R.F., 1982. Geology of Gander Lake (2D/15) and Gander River (2E/2) area. Newfoundland Dep. Mines Energ., Min. Dev. Div, Rep. 82-4: 56 pp.

Bradley, D.C., 1983. Tectonics of the Acadian orogeny in New England and adjacent Canada. J. Geol., 91: 381-400.

Chorlton, L.B. and Dallmeyer, R.D., 1986. Geochronology of Early to Middle Paleozoic tectonic development in the southwest Newfoundland Gander zone. J. Geol., 94; 67-89.

Church, W.R. and Stevens, R.K., 1971. Early Paleozoic ophiolite complexes of the Newfoundland Appalachians as mantle-oceanic crust sequences. J, Geophys. Res., 76: $1460-1466$.

Colman-Sadd, S.P., 1980. Geology of south-central Newfoundland and evolution of the eastem margin of Iapetus. Am. J. Sci., 280: $991-1017$.

Colman-Sadd, S.P., 1982. Two-stage continental collision and plate driving forces. Tectonophysics, 90: 263-282.

Colman-Sadd, S.P. and Swinden, H.S., 1984. A tectonic window in central Newfoundland? Gcological evidence that the Appalachian Dunnage Zone may be allochthonous. Can. J. Earth Sci., 21: 1349-1367.

Coney, P.J., Jones, D.L. and Monger, J.W.H., 1980. Cordilleran suspect terranes. Nature, 288: 329-333.

Currie, K.L., Pajari, G.E and Pickerill, R.K., 1979. Comments on the boundaries of the Davidsville Group, northeastern Newfoundland. Geol. Surv. Can., Pap. 80-1A: 115-118.
Dean. P.L., 1978. The volcanic stratigraphy and metallogeny of Notre Dame Bay, Newfoundland. Memorial Univ. Newfoundland, St. Johns, Nfld., Geol. Rep., 7: 205 pp.

Dean, P.L. and Strong, D.F., 1977. Folded thrust faults in Notre Dame Bay, Central Newfoundland. Am. J. Sci., 277: 97-108.

Dewey, J.F., 1969. Evolution of the Appalachian/Caledonian orogen. Nature, 222: 124-129.

Dewey, J.F. and Bird, J.M., 1971. Origin and emplacement of the ophiolite suite: Appalachian ophiolites in Newfoundland. J. Geophys. Res., 76: 3179-3206.

Dewey, J.F. and Shackleton, R.M., 1984. A model for the evolution of the Grampian tract in the early Caledonides and Appalachians. Nature, 312: 115-121.

Dewey, J.F., Kennedy, M.J. and Kidd, W.S.F., 1983. A geotraverse through the Appalachians of northern Newfoundland. In: N. Rast and F.M. Delany (Editors), Profiles of Orogenic Belts. Am. Geophys. Union. Geodyn. Ser, Vol. 10, pp. 205-242.

Dunning, G.R. and Krogh, T.E., 1985. Geochronology of ophiolites of the Newfoundland Appalachians. Can. J. Earth Sci, 22: 1659-1670.

Gates, A.E., Simpson, C. and Glover, L., 1986. Appalachian Carboniferous dextral strike-slip faults: an example from Brookneal, Virginia. Tectonics, 5: 119-133,

Hanmer, S., 1981. Tectonic significance of the northeasterly Gander Zone, Newfoundland: an Acadian ductile shcar zone. Can. J. Earth Sci., 18: 120-135.

Haworth, R.T., Lefort, J.P. and Miller, H.G., 1978. Geophysical evidence for an east-dipping Appalachian subduction zone beneath Newfoundland. Geology, 6: 522-526.

Hiscott, R.N., 1984. Ophiolitic rocks for Taconic-age flysch: trace element evidence. Geol. Soc. Am. Bull., 95: 1261-1267.

Jacobi, R.D. and Schweickert, R.A., 1976. Implications of new data on stratigraphic and structural relations of Ordovician rocks on New World Island, north-central Newfoundland (abstract). Geol. Soc. Am., Abstr. Progr., 8: 206.

Jacobi, R.D. and Wasowski, J.J, 1985. Geochemistry and plate-tectonic significance of the volcanic rocks of the Summerford Group, north-central Newfoundland. Geology, 13: $126-130$.

Karig, D.E and Sharman, G.F., 1975. Subduction and accretion in trenches. Geol. Soc. Am. Bull, 86: 377-389.

Karlstrom, K.E., 1983. Reinterpretation of Newfoundland gravity data and arguments for an allochthonous Dunnage zone. Geology, 11: 263-266.

Karlstrom, KE, Van der Pluijm, B.A. and Williams, P.F. 1982. Structural interpretation of the eastern Notre Dame Bay area, Newfoundland: regional post-Middle Silurian thrusting and asymmetrical folding. Can. J. Earth. Sci., 19: $2325-2341$.

Karlstrom, K.E. van der Pluijm. B.A. and Williams. P.F., 1983. Sedimentology of Upper Ordovician-Silurian sequences on New World Island, Newfoundland: separate fault-controlled basins?: Discussion. Can. J. Earth Sci., 20: $1757-1758$. 
Kay, M., 1972. Dunnage Mélange and Lower Paleozoic deformation in northeastern Newfoundland. Int. Geol. Congr., 24th, 3: 122-133.

Kay, M., 1976. Dunnage Mélange and subduction of the Protoacadic Ocean, northeast Newfoundland. Geol. Soc. Am., Spec. Pap. 175: 49 pp.

Kay, M. and Colbert, E.H., 1965. Stratigraphy and life history. Wiley, New York, N.Y, 736 pp.

Kay, M. and Williams, H., 1963. Ordovician-Silurian relationships on New World Island, Notre Dame Bay, northeast Newfoundland (abstr.). Geol. Soc. Am., 74: 807.

Kean, B.F. and Strong, D.F., 1975. Geochemical evolution of an Ordovician island arc of the central Newfoundland Appalachians. Am. J. Sci., 275: 97-118.

Kean, B.F., Dean, P.L. and Strong, D.F., 1981. Regional geology of the Central Volcanic Belt of Newfoundland. In: E.A. Swanson, D.F. Strong and J.G. Thurlow (Editors), The Buchans Orebodies: Fifty Years of Geology and Mining. Geol. Assoc. Can, Spec. Pap. 22: 65-78.

Keen, C.E., Keen, M.J., Nichols, B., Reid, I., Stockmal, G.S., Colman-Sadd, S.P., O’Brien, S.J., Miller, H., Quinlan, G., Willliams, II. and Wright, J., 1986. Deep seismic reflection profile across the northern Appalachians. Geology, 14: 141-145.

Kennedy, M.J., 1975. Repetitive orogeny in the northeastern Appalachians-new plate models based upon Newfoundland examples. Tectonophysics, 28: 39-87.

Kennedy, M.J. and McGonigal, M., 1972. The Gander Lake and Davidsville Groups of northeastern Newfoundland: new data and geotectonic implications. Can. J. Earth Sci., 9: 452-459.

Kidd, W.S.F., 1977. The Baie Verte Lineament, Newfoundland: ophiolite complex floor and mafic volcanic fill of a small Ordovician marginal basin. In: M. Talwani and W.C. Pittman (Editors), Island Arcs, Deep Sea Trenches and Back-Arc Basins. Am. Geophys. Union, M. Ewing Ser., 1: 407-418.

Knipe, R.J. and Needham, D.T., 1985. Deformation processes in accretionary wedges-examples from the southwestern margin of the Southern Uplands, Scotland. In: M.P. Coward and A.C. Ries (Editors), Collision Tectonics. Geol. Soc. London, Spec. Publ., 19: 51-67.

Kusky, T.M. and Kidd, W.S.F., 1985. Middle Ordovician conodonts from the Buchans Group, central Newfoundland, and their significance for regional stratigraphy of the Central Volcanic Belt: Discussion. Can. J. Earth Sci., 22: 484-485.

Legget, J.K., McKerrow, W.S. and Soper, N.J., 1983. A model for the crustal evolution of southern Scotland. Tectonics, 2: 187-210.

Leggett, J.K., McKerrow, W.S., Morris, J.H., Oliver, G.J.H. and Philips, W.E.A., 1979. The northwestern margin of the Iapetus Ocean. In: A.L. Harris, C.H. Holland and B.E. Leake (Editors), The Caledonides of the British Isles-reviewed. Geol. Soc. London, Spec. Publ., 8: 499-511.

McKerrow, W.S., 1983. The northwest margin of the Iapetus
Ocean during the Early Paleozoic. In: C.L. Drake and J.S. Watkins (Editors), Continental Margin Processes. Am. Assoc. Pet. Geol., Mem., 34: 521-533.

McKerrow, W.S. and Cocks, R.L.M., 1977. The location of the Iapetus Ocean suture in Newfoundland. Can. J. Earth Sci., 14: $488-495$.

McKerrow, W.S. and Cocks, L.R.M., 1978. A lower Paleozoic trench-fill sequence, New World Island, Newfoundland. Geol. Soc. Am. Bull., 89: 1121-1132.

McKerrow, W.S., Leggett, J.K. and Eales, M.H., 1977. Imbricate thrust model of the Southern Uplands of Scotland. Nature, 267: 237-239.

Miller, H.G., 1984. Comment on "Reinterpretation of Newfoundland gravity data and arguments for an allochthonous Dunnage zone". Geology, 12: 60-61.

Nelson, K.D., 1981. Melange development in the Boones Point Complex, north-central Newfoundland. Can. J. Earth Sci., 18: $433-442$.

Neuman, R.B., 1984. Geology and paleobiology of islands in the Ordovician Iapetus Ocean: review and implications. Geol. Soc. Am. Bull., 95: 1188-1201.

Osberg, P.H., 1978. Synthesis of the geology of the northeastern Appalachians, U.S.A. Geol. Surv. Can., Pap. 78-13: 137-147.

Pajari, G.E. and Currie, K.L., 1978. The Gander Lake and Davidsville Groups of northeastern Newfoundland: a reexamination. Can. J. Earth. Sci., 15: 708-714.

Pajari, G.E., Pickerill, R.K. and Currie, K.L., 1979. The nature, origin and significance of the Carmanville ophiolitic melange, northeastern Newfoundland. Can. J. Earth Sci., 16: 1439-1451.

Pickcrill, R.K., Pajari, G.E., Currie, K.L. and Berger, A.R., 1978. Carmanville map-area, Newfoundland; the northeastern end of the Appalachians. Geol. Surv. Can., Pap. 78-1A: 209-216.

Reusch, D.N., 1983. The New World Island complex and its relationship to nearby formations, north-central Newfoundland. Unpubl. M.Sc. thesis, Memorial Univ. Newfoundland, St. Johns, Nfld.

Rodgers, J., 1965. Long point and Clam Bank Formations, western Newfoundland. Geol. Assoc. Can., Proc., 16: 83-94

Rodgers, J., 1982. The life history of a mountain range -the Appalachians. In: K. Hsü (Editor), Mountain Building Processes. Academic Press, New York, pp. 229-241.

Schenk, P.E., 1978. Synthesis of the Canadian Appalachians. Geol. Surv. Can., Pap. 78-13: 111-136.

Shanmugam, G. and Lash, G.G., 1982. Analogous tectonic evolution of the Ordovician foredeeps, southern and central Appalachians. Geology, 10: 562-566.

Stringer, P. and Treagus, J.E., 1981. Asymmetrical folding in the Hawick rocks of the Galloway area, Southern Uplands. Scott. J. Geol., 17: 129-148.

Strong, D.F., 1977. Volcanic regimes of the Newfoundland Appalachians. In: W.R.A. Baranger, L.C. Coleman and J.M. Hall (Editors), Volcanic Regimes in Canada. Geol. Assoc. Can., Spec. Pap. 16: 61-90. 
Strong, D.F., Dickson. W.L., O'Driscoll, C.F., Kean, B.F. and Stevens, R.K.. 1974. Geochemical evidence for eastward Appalachian subduction in Newfoundland. Nature, 248: 37-39.

Swinden, H.S. and Thorpe, R.I., 1984. Variations in style of volcanism and massive sulphide deposition in Early to Middle Ordovician island-arc sequences of the Newfoundland Central Mobile Belt. Econ. Geol.: 79, 1596-1619.

Thurlow. J.G.. 1981. The Buchans Group: its stratigraphic and structural setting. In: E.A. Swanson, D.F. Strong and J.G. Thurlow (Editors), The Buchans Orebodies: Fifty Years of Geology and Mining. Geol. Assoc. Can., Spec. Pap. 22: 79-90.

Uyeda, S. and Kanamori, H., 1979. Back-arc opening and the mode of subduction. J. Geophys. Res., 84: 1049-1061.

Van der Pluim, B.A., 1984a. Geology and microstructures of eastern New World Island, Newfoundland and implications for the northern Appalachians. Unpubl. Ph.D. thesis, Univ. New Brunswick. Fredericton, N.B.

Van der Pluijm, B.A., 1984b. Geology of eastern New World Island, Newfoundland: a deformed accretionary terrane (abstr.). Geol. Soc. Ann, Abstr. Progr., 16: 68.

Van der Pluijm, B.A., 1986. Geology of eastern New World Island, Newfoundland: an accretionary terrane in the northeastern Appalachians. Geol. Soc. Am. Bull, 97 : 932-945

Van der Pluijm, B.A. and Williams, P.F., 1985. Fault controlled stratigraphic repetition in the Notre Dame Bay area. Newfoundland (abstr). Geol. Assoc. Can., Progr. Abstr., 10.

Van Staal, C.R., 1985. The structure and metamorphism of the Brunswick Mines area, Bathurst, New Brunswick, Canada. Unpubl. Ph.D. thesis, Univ. New Brunswick, Fredericton. N.B.

Wasowski, J.J. and Jacobi, R.D., 1985. Geochemistry and tectonic significance of the mafic volcanic blocks in the Dunnage Mélange, north-central Newfoundland. Can. J. Earth Sci., 22: 1248-1256.

Watson, M.P.. 1981. Submatine fan deposits of the Upper Ordovician-Lower Silurian Milleners Arm Formation, New World Island, Newfoundland. Unpubl. Ph.D. thesis, Univ. Oxford, Oxford.

Williams, H., 1964. The Appalachians in northeastern Newfoundland-a two sided symmetrical system. Am. J. Sci. 262: $1137-1158$.
Williams, H., 1975. Structural succession, nomenclature, and interpretation of transported in Western Newfoundland. Can. J. Earth Sci., 12: 1874-1894.

Williams, H. (compiler), 1978a. Tectonic-lithofacies map of the Appalachian Orogen. Memorial Univ. Newfoundland, Map 1 .

Williams, H., 1978b. Geological development of the northern Appalachians: its bearing on the evolution of the British Isles. In: D.R. Bowes and B.E. Leake (Editors), Crustal Evolution in Northwestern Britain and Adjacent Regions. Seal House Press, Liverpool, pp. 1-22.

Williams, H. 1979. Appalachian orogen in Canada. Can. I. Earth Sci, 16: 792-807.

Williams, H., 1984. Miogeoclines and suspect terranes of the Caledonian-Appalachian Orogen: tectonic patterns in the North Atlantic region. Can. J. Earth Sci., 21: 887-901.

Williams, H. and Hatcher, R.D., 1982. Suspect terranes and accretionary history of the Appalachian orogeny. Geology, 10: $530-536$.

Williams, H. and Hatcher, R.D., 1983. Appalachian suspect terranes. Geol. Soc. Am., Mem., 158; 33-53.

Williams. II. and Payne, J.G.. 1975. The Twillingate Granite and nearby volcanic groups: an island arc complex in Northeast Newfoundland. Can. J. Earth Sci., 12: 982-995.

Williams, H., Kennedy, M.J and Neale, E.R.W., 1972. The Appalachian structural province. In: R.A. Price and R.J.W. Douglas (Editors), Variations in Tectonic Styles in Canada. Geol. Assoc. Can., Spec. Pap., 11: 181-261.

Williams, H. Kennedy, M.J. and Neale, E.R.W.. 1974. The northeastward termination of the Appalachian Orogen. In: A.E.M. Nairn and F.G. Stehli (Editors), The Ocean Basins and Margins. Plenum Press, New York, N.Y., pp. 79-123.

Williams, P.F., 1984. Deformation in the New World Island area, Newfoundland: late stage transcurrent faulting (abstr.). Geol. Soc. Am. Bull., Abstr. Progr., 16: 71.

Wilson, J.T. 1966. Did the Atlantic close and then re-open? Nature, 211: 676-681.

Wilton, D.H.C., 1983. The geology and structural history of the Cape Ray Fault zone in southwestern Newfoundland. Can. J. Earth Sci., 20: 1119-1133.

Wonderley. P.F. and Neuman, R.B., 1984. The Indian Bay Formation: fossiliferous Early Ordovician volcanogenic rocks in the northern Gander Terrane, Newfoundland, and their regional significance. Can. J. Earth Sci., 21: 525-532. 